\title{
The leatherback turtle Dermochelys coriacea (Vandelli, 1761) in the Bay of Biscay and the North East Atlantic
}

\author{
Nagore Zaldua-Mendizabal ${ }^{*}$, Raúl Castro Uranga ${ }^{2}$ \& Carlos García-Soto ${ }^{3}$ \\ ${ }^{1}$ Aranzadi Society of Sciences, Department of Herpetology. Itsas Dortoka Programme. \\ ${ }^{2}$ AZTI-Tecnalia Marine Research Unit \\ ${ }^{3}$ Spanish Oceanographic Institute \\ *nzaldua@aranzadi-zientziak.org
}

\section{ABSTRACT}

This paper is a synthesis of our knowledge on the leatherback turtle Dermochelys coriacea (Vandelli 1761) in the Bay of Biscay and in the North East Atlantic. Numerous sightings in these two regions lead us to believe that they are foraging areas for this critically endangered (CR) species (IUCN, 2011). Its conservation does not depend solely and exclusively on mitigating the anthropogenic interactions, but also in the protection and use of its habitat. For this reason we will highlight the importance that Marine Protected Areas (MPA) could have and the need for new areas to be declared along the European Community coastline and within the vast bodies of water of the Bay of Biscay and the North East Atlantic.

KEY WORDS: Dermochelys coriacea, leatherback turtle, conservation, Bay of Biscay, North East Atlantic.

\section{RESUMEN}

En este artículo pretendemos exponer el conocimiento que se tiene sobre la tortuga laúd Dermochelys coriacea (Vandelli, 1761) en el golfo de Bizkaia. Existen zonas en el golfo de Bizkaia y el Atlántico Noreste de gran utilidad para D. coriacea, que se pueden definir como zonas de alimentación para la especie en peligro crítico de extinción (CR) (IUCN, 2011). La conservación de la especie no depende única y exclusivamente de la mitigación de las interacciones entre la especie y las actividades antropogénicas directas con ésta sino también con los hábitats y el uso que hagamos de los mismos. Por todo ello, queremos subrayar la importancia que pueden tener las Áreas Marinas Protegidas y la necesidad de que se declaren nuevas zonas en nuestras costas y aguas comunitarias europeas.

PALABRAS CLAVE: Dermochelys coriacea, tortuga laúd, conservación, golfo de Bizkaia, Atlántico Noreste.

\begin{abstract}
LABURPENA
Lan honen bitartez, Bizkaiko golkoan larruzko dortoka Dermochelys coriacea-z (Vandelli, 1761) ezagutzen dena aurkeztu nahi izan dugu. Bizkaiko golkoan eta Atlantiar Ipar Ekialdean D. coriacea-rentzat garrantzi berezia duten guneak aurkitzen dira, desagertzeko arriskuan katalogatua dagoen (CR) (IUCN, 2011) espezie honentzat elikadura gune bezala definitu daitezkeenak. Giza jarduera batzuek espeziearekiko interakzio zuzena badute ere, hauen murriztea edo ekiditzea ez da kontserbaziorako eman beharreko pauso bakarra hain zuzen ere beste jarduera batzuek habitatetan dituzten ondorioak eta berauen erabilerak ere kontuan hartu beharrekoak dira. Guzti hau dela eta Itsas Eremu Babestuek duten garrantzia azpimarratu nahi dugu bai gure kostaldean baita europar batasuneko uretan ere.
\end{abstract}

GAKO-HITZAK: Dermochelys coriacea, larruzko dortoka, kontserbazioa, Bizkaiko golkoa, Atlantiar Ipar Ekialdea.

\section{INTRODUCTION}

Sea turtles are species, which are not well-known in the Bay of Biscay and the North East Atlantic. Of the seven species existing in the world, the loggerhead sea turtle $\mathrm{Ca}$ retta caretta (Linnaeus, 1758) and the leatherback turtle Dermochelys coriacea (Vandelli, 1761) are the most cited in these areas (BRONGERSMA, 1972; DUGUY, 1997; CAMINAS, 2004; CeRMEÑo et al., 2006). The former belongs to the Cheloniidae family, which includes a further five species; the latter is the sole survivor of the Dermocheliidae family.

The first mention of $D$. coriacea in the Basque Country was published in 1951, and refers to a specimen captured by a bonito fishing boat in Mutriku (NAVAZ \& GOMEZ DE LLANERA 1951). Like the other species of sea turtle, D. coriacea has experienced a drastic reduction in many of its populations over the last few decades (SARTI MARTíneZ, 2000 in IUCN, 2011). For this reason, it is currently protected and classified on the International Union for Conservation of Nature (IUCN) Red List. Although an increase in its populations in recent decades as been observed in the Atlantic, mainly in the Caribbean region (DuTton et al., 2005), and its numbers have stabilized in others, its "critically endangered (CR)" classification assigned by the IUCN (SARTI MARTínEZ, 2000 in IUCN 2011) has not been modified. In Spain, this species is included on the red list of threatened species (CAMINAS, 2004). The cataloguing and protection of these reptiles in the waters of the Basque Country but also in other communities along the Cantabrian coast are still pending.

\section{DISTRIBUTION AND ABUNDANCE OF THE LEA- THERBACK SEA TURTLE IN THE BAY OF BISCAY AND THE NORTH EAST ATLANTIC}

Observation of $D$. coriacea adult individuals in the North East Atlantic, including the Bay of Biscay, is relatively frequent, although published data are scarce. According to a compilation of surveys on sea turtles in Galicia and the Cantabrian coast, 518 individuals of five different species 
were spotted between 1990 and 2005 (CERMEÑo et al. 2006). In this study, D. coriacea was the second most commonly-sighted species (40.7\%), after C. caretta (55\%).

The seasonal pattern of the species in this region was identified by DuguY (1997) and confirmed by MARTIN (2003). According to these authors, D. coriacea visits the Bay of Biscay during the summer (Dugur, 1997; MARTIN, 2003; WITT et al., 2007a). Tracking of individuals have shown that turtles migrate from areas of reproduction in the Western Atlantic (Caribbean, French Guiana) to the North Atlantic using northern branches of the Gulf Stream or North Atlantic Current (HAYs et al., 2004, 2006; ECKERT, 2006; DOYLE, 2007). These ocean frontal regions are known to be highly productive areas and where leatherbacks are known to forage along with a great variety of marine fauna and the resulting fishing fleets (FERRAROLI et al., 2004).

The presence of Leatherbacks is clearly greater on the Galician coast than on the Cantabrian coast, dropping sharply as one travels eastwards. This is probably due to its closer proximity to the North Atlantic Current and to the presence of major foraging areas such as the Galicia Bank.

The male specimens of $D$. coriacea tend to be mainly adult individuals, and on the Cantabrian coast their average size (Curved Carapace Length, $\mathrm{CCL}$ ) is $161.5 \mathrm{~cm}$ $(n=74)$ (CERMEÑO et al., 2006), which is within the range of the sizes of reproducing females among the Atlantic population (CHACÓN-CHAVERRI, 1999; STEWART et al., 2007).

Other studies take other major foraging areas into consideration in the North Atlantic, such as Nova Scotia (Canada) (JAMEs et al., 2005, 2006a, 2007) or the waters north of the Bay of Biscay such as the Irish and Celtic Sea (HAYs et al., 2004, 2006; Houghton et al., 2006; WitT et al., 2007a; FossetTE et al., 2010). During the summer, when primary production decreases in the ocean, the continental slope of the Celtic Sea becomes a major area for the production of plankton (GARCIA-SOTO \& PINGREE, 1998). The tidal front of the Irish Sea (PINGREE \& GRIFFITHS, 1978) is also a significant area for summer plankton production.

The $15{ }^{\circ} \mathrm{C}$ isotherm has been described as the northern distribution limit for this species in waters of the North Atlantic, although it may withstand lower temperatures (MCMAHON \& HAYS, 2006; JAMES et al., 2006b). Other authors (WITT et al., 2007a) postulate isotherms of $10-12{ }^{\circ} \mathrm{C}$.

A clear choice of habitat on the part of $D$. coriacea has been observed when the abundance of gelatinous organisms increases at the end of summer and early autumn (WITT et al., 2007a). The correlation existing between D. coriacea and its prey (mainly gelatinous plankton organisms) has been proven on different occasions in the North Atlantic, both in Canadian waters (JAMES \& HERMAN, 2001) and in Irish Sea waters (Houghton et al., 2006; DoYLE, 2007; FosSETTE et al., 2010) although the effects of environmental conditions on the abundance of prey and predatory behaviour are still unknown (SHERRILL-Mıx et al., 2007).

Observation of $D$. coriacea in the North-East Atlantic tends to be concentrated in the summertime (DUGUY, 1997; Martin, 2003; Penrose \& Gander, 2010). In the case of the Cantabrian coast, there is no established coordinated network of strandings or sightings to help put together information and develop relevant regional coastal reports, as it is the case for the British Isles and France (Witt et al., 2007b; PenRose \& GAnder, 2010; Dell'Amico \& MORINIĖRE, 2010) or in the Mediterranean (e.g.: TOMÁS et al., 2008; CASALE et al., 2010).

Leatherbacks have been sighted off La Rochelle (Dell'Amico \& Morinière, pers. comm.), where there is evidence of abundant jellyfish (SEBASTIAN et al., 2011), as well as a large number of $D$. coriacea strandings. The French coast is characterized by a major fluvial contribution (e.g. Gironde River) and the presence of tidal fronts (PINGREE et al., 1982), which during the summer increase biological production. The departments of Charente-Maritime and Vendée on the French Atlantic Coast are the areas where this species would seem to be most abundant, both in terms of sighted and stranded specimens (DELL'AMICO \& MORINIËRE, 2010). This fact is explained by local productive processes, which include - among others - the vertical mixture of the continental slope waters and the topographic effects of the banks. Figure 1 shows concentrations of plankton in the mouth of the Gironde, the Cantabrian outcrop and ocean whirlpool region. The concentration of plankton on these structures is greater as one travels further away from the interior of the Bay of Biscay (GARCIA-Soto et al., 2002).

In a study of $D$. coriacea migratory behaviour using satellite tagging in the North East Atlantic (DoYLE et al., 2007b), an individual increased the time it remained in one of these ocean structures for several months, validating their good foraging conditions. This behaviour has been observed by other authors and in other species of sea turtle, thereby confirming that whirlpools and eddies are associated with a great abundance of prey (SHOOP \& KENNEY, 1992; LUTCAVAGE, 1996; LUSCHI et al., 2003; FERRAROLI et al., 2004; HAYs et al., 2006; ECKERT, 2006; PoLOVINA et al., 2006). The presence of swoddies or Slope

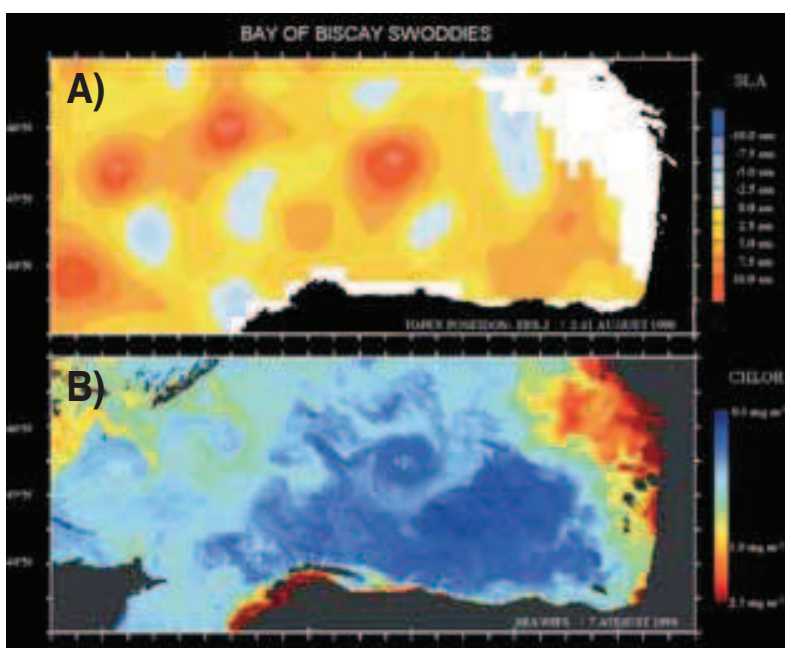

Fig. 1.- Swoddies in the Bay of Biscay in August 1998. (A) Sea level (cm) and (B) Concentration of phytoplankton (mg Chlorophyll/ $\mathrm{m}^{3}$ ). (GARCIA-SOTO et al., 2002). 
Water Oceanic Eddies common in the south of the Bay of Biscay (GARCIA-SOTO et al., 2002) could explain the increase presence of sea turtles in the area in the summertime.

\section{ANTHROPOGENIC IMPACTS}

Traditionally, the main causes of decline of sea turtle populations, has been the loss of nesting beaches and other threats that affect reproduction (LUTCAVAGE et al., 1997). Bycatch during fishing manoeuvres (Dugur et al., 1998; LEWISON et al., 2004a, 2004b; LEWISON \& CROWDER, 2007; PECKHAM et al., 2007; BÁEZ et al., 2007 and 2008; WALLACE et al., 2008), climate change (PoloczANSKA et al., 2009), the loss of habitat both in egg-laying areas and on the open sea (LUTZ \& MUSICK, 1997; BOLTEN \& WITHERINGTON, 2003) and sea pollution due to heavy metals and solid residues (Duguy et al., 1998; Mrosovsky et al., 2009) are factors responsible for the decline in populations worldwide.

In the specific case of $D$. coriacea, mortality factors identified on the French Atlantic coast have been the ingestion of plastics, collision with vessels and bycatch by fisheries (Duguy, 1997; Duguy et al., 1998). On the Basque coast and the rest of the Cantabrian coast, although specific studies are inexistent, similar causes of occasional stranding are most likely to be blamed.

\section{Fishing and bycatch}

There is a wide range of examples in the literature regarding bycatch of marine megafauna by different fisheries worldwide: dolphins in purse seine nets caught by tuna fishing boats, albatrosses caught by longline fishing and sea turtles caught by shrimp trawling, or by surface Iongline fishing (SILVANI et al., 1999; HALL et al., 2000; LEWISON et al., 2004a; LEWISON \& CROWDER, 2007; BÁEZ et al., 2007 and 2008; MRAG LTD, 2008).

Although it is quite well documented that large-scale industrial fishing has given rise to a drop in sea turtle populations, not enough attention has been paid to the impact of small-scale fisheries on non-target populations of these species. The great majority (99\%) of the 51 million fishermen in the world fish in coastal waters (within 12 miles), not surprisingly these coastal habitats are also frequented by numerous migratory marine species with a high potential for bycatch. As a result of this overlap, fisheries may constitute one of the greatest threats to endangered species (PECKHAM et al., 2007). Artisanal fisheries would seem as a whole to be responsible for bycatch on a major scale. This decreases the effectiveness of the means for reducing bycatch which is being put into practice by industrial fisheries worldwide (Peckham et al., 2007; Alfaro-Shigueto et al., 2008; AlfaroSHIGUETO et al., 2010). Proposals to reduce bycatch would benefit from studies quantifying the bycatch by small-scale fisheries and the impact on habitat of endangered species (SOrCAn et al., 2008).

There are large gaps in our knowledge about bycatch and closer monitoring of this is needed, particularly in less studied regions (CARRERAs et al., 2004; LEWIson et al., 2004b; TOMÁs et al., 2008; WALLACE et al., 2010;
Álvarez de QueVEDo et al., 2010). The most recent report by the study group on the bycatch of protected species by the International Council for the Exploration of the Sea (ICES, 2008), refers to the lack of funding for onboard observer programmes and reflects the scant attention paid to bycatch of protected species manifested by most member countries.

A survey conducted systematically with fishermen was carried out for the first time in the Basque Country in 2010 (ZALDUA-MENDIZABAL, 2010) to assess possible interaction between coastal fisheries (47 coastal vessels polled out of a total of 193) and sea turtles in waters of the Bay of Biscay. From the data obtained about bycatch, which referred exclusively to $C$. caretta, and the distribution of the fishing effort during 2009, a Catch per Unit Effort value (CPUE) was obtained of 0.0018 turtles/month/vessel. It should be pointed out that vessels were not boarded and therefore the CPUE values obtained from the survey could not be validated (ZaLDUA-MENDIZABAL, 2010). The distribution and summer seasonal presence of $D$. coriacea in the area were also confirmed in during this study (Fig. 2). Furthermore, the existence of hot points of great importance for conservation of this species in the Bay of Biscay and adjacent areas of the North East Atlantic were also identified.

The conclusion drawn from the assessment work carried out on the bycatch of sea turtles by the Basque coastal fishing fleet shows that the density of turtles in waters near the coast is low, which means interaction with fishing fleets operating in these waters would appear to be limited and does not entail a potential threat to stocks in the Bay of Biscay (Table 1). Conversely, the survey reflected a greater density of sea turtles in areas further away from the coast (Galicia Bank, Celtic Sea and Gran Sol), which could be explained by the presence of a larger continental shelf than off the coasts of France and Ireland, which would in turn imply greater availability of food (HOUGHTON et al., 2006; SIMS et al., 2006; WITT et al., 2007a; CAUT et al., 2008; FossetTE et al., 2010).

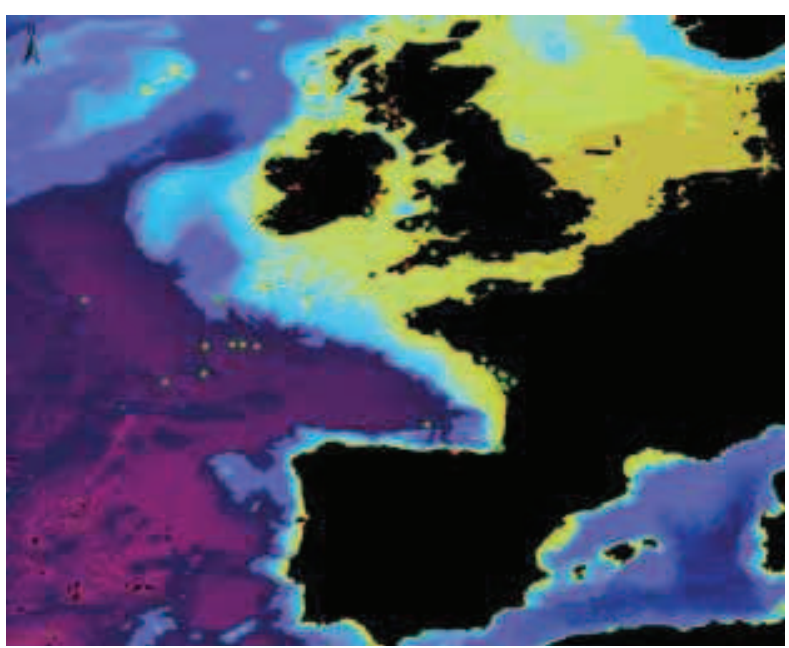

Fig. 2.- D. coriacea sightings and strandings in the Bay of Biscay and closest areas in 2009 


\begin{tabular}{|l|ccccc|}
\hline \multicolumn{1}{|c|}{$\begin{array}{c}2009 \\
\text { Species }\end{array}$} & \multicolumn{2}{|c|}{ Sightings } & \multicolumn{2}{c|}{$\begin{array}{c}\text { Basque Country } \\
\text { Strandings }\end{array}$} \\
\hline & Alive & Dead & Alive & Dead & Alive \\
\hline Caretta caretta & 1 & 0 & 3 & 1 & 2 \\
\hline Dermochelys coriacea & 4 & 0 & 0 & $1^{*}$ & 0 \\
\hline Indeterminate & 1 & 0 & 0 & 0 & 0 \\
\hline TOTALS & 6 & 0 & 3 & 2 & 0 \\
\hline
\end{tabular}

\begin{tabular}{|c|c|c|c|c|c|c|}
\hline \multirow{3}{*}{$\begin{array}{c}\mathbf{2 0 0 9} \\
\text { Species }\end{array}$} & \multicolumn{6}{|c|}{ FRANCE } \\
\hline & \multicolumn{2}{|c|}{ Sightings } & \multicolumn{2}{|c|}{ Strandings } & \multicolumn{2}{|c|}{ Bycatch } \\
\hline & Alive & Dead & Alive & Dead & Alive & Dead \\
\hline Caretta caretta & 1 & 0 & 8 & 6 & $1^{* *}$ & 0 \\
\hline Dermochelys coriacea & 13 & 0 & 0 & 9 & 0 & 0 \\
\hline Indeterminate & 0 & 0 & 0 & 0 & 0 & 0 \\
\hline TOTALS & 14 & 0 & 8 & 15 & 1 & 0 \\
\hline
\end{tabular}

\begin{tabular}{|l|cccccc|}
\hline \multicolumn{1}{|c|}{$\begin{array}{c}2009 \\
\text { Species }\end{array}$} & \multicolumn{2}{|c|}{ Sightings } & UNITED KINGDOM \& IRELAND \\
Strandings & Alive & Dead & Alive \\
\hline & Alive & Dead & 0 & 5 & 4 & 0 \\
\hline Caretta caretta & 0 & 1 & 0 & 5 & 0 \\
\hline Dermochelys coriacea & 15 & 1 & 0 & 1 & 0 \\
\hline Indeterminate & 7 & 2 & 5 & 10 & 0 \\
\hline TOTALS & 22 & Dead & 0 \\
\hline
\end{tabular}

Table 1.- Strandings, sightings and bycatch of sea turtles in the Basque Country, year 2009. Comparative data from France (DELL'AmICo et al., 2010), United Kingdom and Ireland (PENROSE \& GANDER, 2010) is also included, in addition to a stranding of D. coriacea in Castro Urdiales (Cantabria; Alejandro Gómez Iriberri) $\left(^{*}\right)$ and a bycatch of $C$. caretta in France (31 ${ }^{\text {st }}$ December 2008) $\left(^{* *}\right)$.

\section{Ingestion of solid residues}

Generally speaking, a high mortality rate of sea turtle is due to the ingestion of residues (Dugur, 1997; Dugur et al., 1998), although D. coriacea is especially sensitive to this threat due to its trophic specialisation (FossetTe et al., 2010; JAMES \& HERMAN, 2001), with its diet consisting of gelatinous organisms, salpids, jellyfish and others. Plastic bags and residues with a similar appearance to its prey represent a great threat. A sea turtle study carried out on the Basque coast, in which autopsies carried out on 43 individuals, resulted in 22 individuals with plastic residues in their digestive tract (51.1 $\%)$. The plastic residues found were of diverse origin, and in some cases very large (Duguy et al., 1998).

\section{IMPORTANT AREAS FOR CONSERVATION OF THE LEATHERBACK TURTLE IN THE BAY OF BIS- CAY AND NORTH EAST ATLANTIC}

Dermochelys coriacea plays a key ecological role as a major predator of jellyfish and gelatinous zooplankton (GIBBSON \& RICHARDSON, 2009; FosSETtE et al., 2010). The decrease in numbers of this species together with that of other key predators such as some commercially-significant species of fish could have serious repercussions on population control of the species on which they prey and bring about a change that could in turn have unforeseen consequences. Furthermore, they are responsible for passing on nutrients between foraging areas and nesting beaches (BOUCHARD \& BJORNDAL, 2000) and play a major role as an oasis in the middle of the oceans where birds and fish can rest and seek protection from predators (PITMAN, 1993). These are just a few examples of the ecological importance of $D$. coriacea in marine and terrestrial ecosystems. We do not know how the reduction in its populations could be affect the ecosystems, whereby plans for its conservation and the protection of habitats where it carries them out are essential. In the case of the Bay of Biscay and the North East Atlantic, there are three foraging areas of great importance to D. coriacea (Fig. 3): (1) the Galicia Bank (ECKERT, 2006) (an area being studied as a possible Marine Protected Area), (2) Irish waters (Irish Sea and Celtic Sea; Houghton et al., 2006) to the north of the Bay of Biscay, and (3) a third area that has yet to be confirmed off the coast of La Rochelle, the Pertuis Charentais, which is currently classified as a Site of Community Importance (SCl) in the Gironde estuary, on the French Atlantic coast. This last-mentioned has shown a high number of sighted and stranded $D$. coriacea specimens (Doyle \& Morinière, pers. comm.; see Fig. 4), in addition to a high concentration of gelatinous zooplankton (Doyle, pers. comm.), and as facing a potential threat from trawling in the vicinity. This place is actually a Protected Marine Area (http://www. aires-marines.fr/L-Agence/Organisation/Missions-d-etude-de-parc/Gironde-Pertuis) and French Government plans to create a marine nature reserve there.

Generally-speaking, the designation of areas of special importance or especially vulnerable ones (Marine Protected Areas) is considered to be one of the most important tools available for protecting species and habitats. In the specific case of the Cantabrian coast, declaring an area an MPA for inclusion in the Natura 2000 Network has not hitherto been a priority in either autonomous or state administrations. The Cabinet declared the first Marine Protected Area in Spain in 2008 in El Cachucho (Asturias). The Galicia Bank is currently being studied, as this is a major habitat for $D$. coriacea 


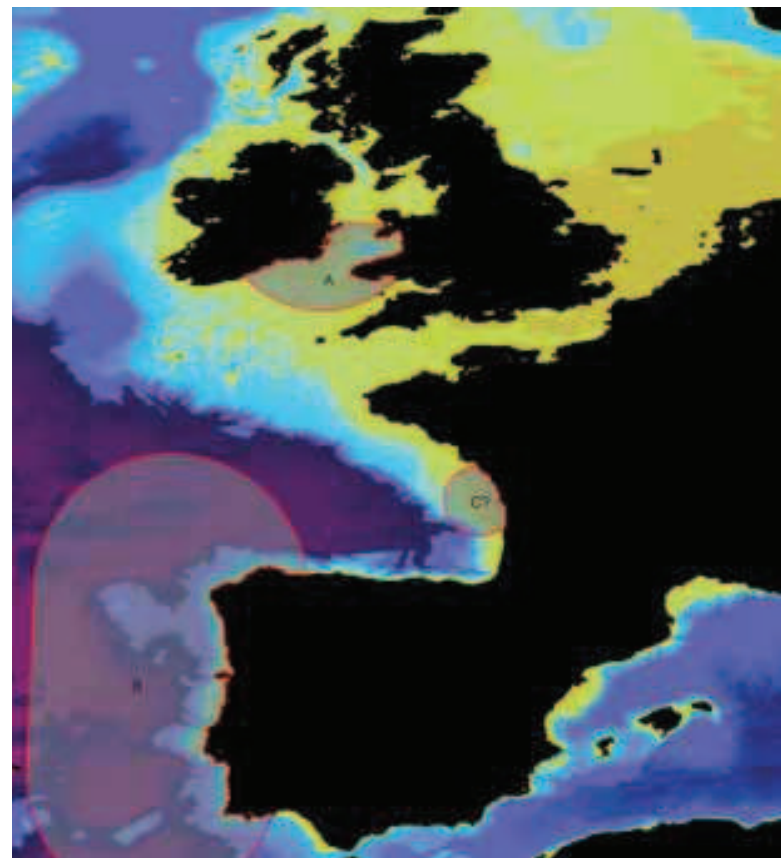

Fig. 3.- D. coriacea foraging grounds in the Nord East Atlantic.

(ECKERT, 2006) and many other species, and a place where a great number of fishing fleets operate, with the resulting possibility of bycatch, collisions and destruction of habitat, etc. For all the aforementioned reasons, management plans are needed to integrate ecosystems, resources and endangered species.

\section{CONCLUSIONS}

Dermochelys coriacea continues to be an unknown species in the Bay of Biscay and the North East Atlantic. Generally speaking, research into conservation of this species is not at present a priority. This is a predator with very few competitors and, given its trophic specialisation, it is

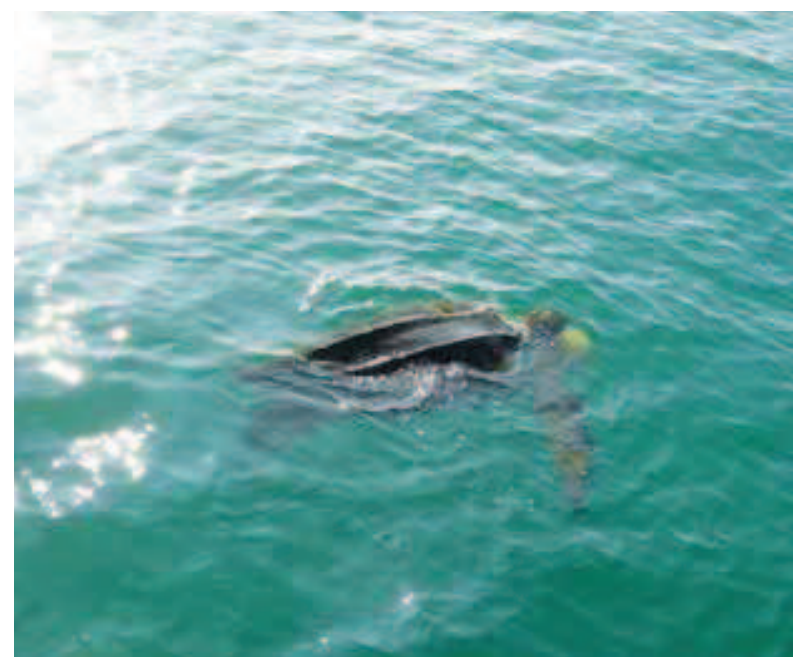

Fig. 4.- D. coriacea feeding on a barrel jellyfish Rhizostoma octopus in front of La Rochelle coastline, Bay of Biscay in 2007. Photography: Bateau École des Douanes, La Rochelle/Aquarium La Rochelle S.A.S. not known whether its absence could alter the trophic network in the foraging areas it frequents. Thus, the influence it has on bringing about changes that would affect these habitats and/or anthropogenic activities carried out in them such as fishing or tourism has not been assessed.

Greater knowledge about the oceanography of the Bay of Biscay, its habitats and species is required in order to understand the relationship existing between the physical-chemical and biological complex in this part of the North East Atlantic.

The conservation of biodiversity and habitats must be made a priority. The creation of MPA is not enough, but it is necessary to ensure that ecosystems are recovered and increase their resilience - also in this area of the North East Atlantic.

\section{ACKNOWLEDGEMENTS}

To the Aranzadi Society of Sciences for the grant awarded to carry out the end-of-master's degree project "Assessment of interaction between fisheries of the Basque Country and sea turtles in the Bay of Biscay", which forms the basis for this study and was made possible by a grant (NZM) awarded by the Aranzadi Society of Sciences, which also takes part in the setting in motion of the Itsas Dortoka Programme.

To Ariñe Crespo for her time and assistance in preparing the distribution maps.

I would like to especially thank three people who have been keys throughout this journey in the course of which we have been able to set up the first working party on sea turtles in the Basque Country: Alberto Gosá, Xabier Rubio and Aitziber Egaña-Callejo, for all the assistance provided and the trust they have placed since the beginning of the Itsas Dortoka Programme.

And of course to all those people who have helped and supported the Itsas Dortoka Programme in one way or another.

\section{REFERENCES}

Alfaro-Shigueto, J., Mangel, J. C., Seminoff, J. A., Dutton, P. H. 2008. Demographic of loggerhead turtles Caretta caretta in the south-eastern Pacific Ocean: fisheries-based observations and implications for management. Endang. Species Res. 5: 129-135.

Alfaro-Shigueto J Mangel, J C Paufelo, M Dutton, P H , SeMinOFF, J. A., GoDLEy, B. J. 2010. Where small scale can have a large impact: Structure and characterization of small-scale fisheries in Peru. Fish. Res. 106(1): 8-17.

Álvarez de Quevedo, I., Cardona, L., de Haro, A., Pubill, E., AgulLAR, A. 2010. Sources of bycatch of loggerhead sea turtles in the western Mediterranean other than drifting longlines. J. Mar. Sci. 67: 677-685.

BÁEZ, J. C., ReAl, R., Garcia-Soto, C., de la Serna, J. M., Macias, D., CAMIÑAS, J. A. 2007. Sea turtle bycatch dependency on distance to the coast irrespective of fishing effort: implications for conservation and fisheries management. Mar. Ecol. Prog. Ser. 338: 249-256. 
Báez, J. C., Real, R., Garcia-Soto, C., Camiñas, J. A. 2008. Reducing sea turtle by-catch in longlines using management of eco-geographical variables. Marginata 17: 40-42.

Bastian, T., Stokes, D., Kellerher, J. E., Hays, G. C., Davenport, J., DOYLE, T. K. 2011. Fisheries by-catch data provide insights into the distribution of the mauve stinger (Pelagia noctiluca) around Ireland. J. Mar. Sci. 68: 436-443.

Bolten, A. B., Witherington, B. E. 2003. Loggerhead Sea Turtles. Smithsonian Institution Press. Washington, D.C, USA.

Bouchard, S. S., BJorndal, K. A. 2000. Sea turtles as biological transporters of nutrients and energy from marine to terrestria ecosystems. Ecology 81(8): 2305-2313.

Brongersma, L. D. 1972. European Atlantic Turtles. Zoologische Verhandelingen 121. E. J. Brill. Leiden.

CAMINANAS, J. A. 2004. Estatus y conservación de las tortugas marinas en España. In: Atlas y Libro Rojo de los Anfibios y Reptiles de España. J. M. Pleguezuelos, R. Márquez, M. Lizana (Eds.): 345-380. Dirección General de Conservación de la Naturaleza Asociación Herpetológica Española. Madrid.

Carreras, C., Cardona, L., Aguilar, A. 2004. Incidental catch of the loggerhead turtle Caretta caretta off the Balearic Islands (western Mediterranean). Biol. Conserv. 117: 321-329.

Casale, P., Affronte, M., Insacco, G., Freggi, D., Vallini, C., Pino D’Astore, P., Basso, R., Paolillo, G., Abbate, G., Argano, R. 2010. Sea turtle strandings reveal high anthropogenic mortality in Italian waters. Aquatic Conserv.: Mar. Freshw. Ecosyst. 20(6): 611-620.

Caut, S., Guirlet, E., Angulo, E., Das, K., Girondot, M. 2008. Isotope Analysis Reveals Foraging Area Dichotomy for Atlantic Leatherback Turtles. PLOS ONE 3(3): e1845. Doi:10.1371/journal.pone.0001845

Cermeño, P., Valeriras, X., López, A., Martinez-Cedeira, J. A., Laria, L. Perez, C. Martinez de Murguía, A García-Castrillo, G. 2006. Varamientos y capturas accidentales en Galicia y mar Cantábrico. In: IX Congreso Luso-Español de Herpetología. X. Rubio (Ed.): 140-141. Sociedad de Ciencias Aranzadi. Donostia-San Sebastián.

Chacón-ChaverRi, D. 1999. Anidación de la tortuga Dermochelys coriacea (Testudines: Dermochelyidae) en Playa Gandoca Costa Rica (1990 a 1997). Rev. Biol. Trop. 47(1-2): 225-236.

Dell'Amico, F., Morinière, P. 2010. Observations de tortues marines en 2008 et 2009 (Côtes Atlantiques Françaises). Ann. Soc. Sci. Nat. Charente-Maritime 10(1): 69-76.

DoYLE, T. K. 2007. Leatherback Sea Turtles (Dermochelys coriacea) in Irish waters. Irish Wildlife Manuals, 32. National Parks and Wildlife Service, Department of the Environment, Heritage and Local Government. Dublin, Ireland.

Doyle, T. K., Houghton, J. D., O'súllleabhain, P. F., Hobson, V. J., MARNELL, F., DAVENPORT, J., HAYS, G. C. 2007. Leatherback turtles satellite-tagged in European waters. Endang. Species Res. 4: 23-31.

Duguy, R. 1997. Les tortues marines dans le Golfe de Gascogne. Ann. Soc. Sci. Nat. Charente-Maritime 8(6): 633-645

Duguy, R., Moriniere, P., Le Milinaire, C. 1998. Facteurs de mortalité observés chez les tortues marines dans le golfe de Gascogne. Oceanol. Acta 21(2): 383-388.

Dutton, D. L., Dutton, P. H., Chaloupca, M., Boulon, R. H. 2005. Increase of a Caribbean leatherback turtle Dermochelys coriacea nesting population linked to long-term nest protection. Biol. Conserv. 126: 186-194.

ECKERT, S. A. 2006. High-use oceanic areas for Atlantic leatherback sea turtles (Dermochelys coriacea) as identified using satellite telemetered location and dive information. Mar. Biol. 149: 1257-1267
Fernandez, E., Álvarez, F., Anadón, R., Barquero, S., Bode, A., Garcia, A., García-Soto, C., GIL, J., Gonzalez, N., IrIARTE, A., Mouriño, B., Rodriguez, F., Sánchez, R., Teira, E., Torres, S. Valdés, L., Varela, M., Varela, R., Zapata, M. 2004. The spatial distribution of plankton communities in a Slope Water anticyclonic Oceanic eDDY (SWODDY) in the southern Bay of Biscay. J. Mar. Biol. Ass. U. K. 84: 501-517.

Ferraroli, S., Georges, J. Y., Gaspar, P., Le Maho, Y. 2004. Where sea turtles meet fisheries. Nature 429: 521-522.

Fossette, S., Hobson, V. J., Girard, C., Calmettes, B., Gaspar, P., GEORGES, J., HAYS, G. C. 2010. Spatio-temporal foraging patterns of a giant zooplanktivore, the leatherback turtle. J. Mar. Syst. 81: 225-234.

Garcia-Soto, C. PingreE, R. D. 1998. Late autumn distribution and seasonality of chlorophyll a at the shelf-break/slope region of the Armorican and Celtic shelf. J. Mar. Biol. Ass. U. K. 78: 17- 33.

Garcia-Soto, C., Pingree, R. D., Valdés, L. 2002. Navidad development in the Southern Bay of Biscay: climate change and swoddy structure from Remote Sensing and in situ measurements. J. Geophys. Res. 107(C8): 3118.

GARCIA-Soto, C. 2005. Oceanografía del Golfo de Vizcaya. In: El Cimarrón del Atlantico Norte y Mediterráneo. J.L. Cort (Ed.): 66-69. Servicio de Publicaciones del IEO. Madrid.

GibBons, M. J., Richardson, A. J. 2009. Patterns of jellyfish abundance in the North Atlantic. Hydrobiologia 616: 51-65.

Hall, M. A., Alverson, D. L., Metuzals, K. I. 2000. Bycatch: Problems and Solutions. Mar. Pollut. Bull. 41(1-6): 204-219.

Hays, G. C., Hobson, V. J., Metcalfe, J. D., Righton, D., Sims, D. 2006. Flexible foraging movements of leatherback turtles across the North Atlantic Ocean. Ecology 87(10): 2647-2656

Hays, G. C., Houghton, J. D. R., Myers, E. A. 2004. Endangered species: Pan-Atlantic leatherback turtle movements. Nature 429: 522.

Houghton, J. D. R., Doyle, T. K., Wilson, M. W., DAVEnPort J., HAYS, G. C. 2006. Jellyfish aggregations and leatherback turtle foraging patterns in a temperate coastal environment. ECology 87(8): 1967-1972.

ICES. 2008. Report of the Study Group for Bycatch of Protected Species (SGBYC), 29-31 January 2008, ICES, Copenhagen, Denmark ICES CM 2008/ACOM 48.

Isla, J. A., Ceballos, S., Huskin, I., Anadon, R., Alvarez-Marques, F. 2004. Mesozooplankton distribution, metabolism and grazing in an anticyclonic slope water oceanic eddy (SWODDY) in the Bay of Biscay. Mar. Biol. 145: 1201-1212.

IUCN. 2011. IUCN Red List of Threatened Species. Version 2011.1. <wuw.iucnredlist.org > . Downloaded on 30 September 2011.

James, M. C., Herman, T. B. 2001. Feeding of Dermochelys coariacea on Medusae in the Northwest Atlantic. Chelonian Conserv. Biol. 4: 202- 205

James, M. C., Ottesmeyer, C. A., Myers, R. A. 2005. Identification of high-use habitat and threats to leatherback sea turtle in northern waters: new directions for conservation. Ecol. Lett. 8: 195-201.

James, M. C., Sherrill-Mix, S. A., Martin, K., Myers, R. A. 2006 a. Canadian waters provide critical foraging habitat for leatherback sea turtles. Biol. Conserv. 133: 347-357.

James, M. C., DavenPort, J., Hays, G. C. 2006b. Expanded thermal niche for a diving vertebrate: A leatherback turtle diving into near-freezing water. J. Exp. Mar. Biol. Ecol., 335: 221-226.

James, M. C., Sherrill-Mix, S. A., Myers, R. A. 2007. Population characteristics and seasonal migrations of leatherback sea turtles at high latitudes. Mar. Ecol. Prog. Ser. 337: 245-254. 
Lewison, R. L., Crowder, L. B., Read, A. J., Freeman, S. L. 2004 a Understanding impacts of fisheries bycatch on marine megafauna. Trends Ecol. Evol. 19: 598-604.

Lewison, R. L., Freeman, S. A., Crowder, L. B. 2004b. Quantifying the effects of fisheries on threatened species: the impact of pelagic longlines on loggerhead and leatherback sea turtles. Ecol. Lett. 7: 221-231.

Lewison, R. L., Crowder, L. B. 2007. Putting longline bycatch of sea turtles into perspective. Conserv. Biol. 21: 79-86.

Luschi, P., Sale, A., Mencacci, R., Hughes, G. R., Lutjeharms, J. R. E., PAPI, F. 2003. Current transport of leatherback sea turtles (Dermochelys coriacea) in the ocean. Proc. R. Soc. Lond. B (Suppl.) 270: S129-S132.

LutCAVAgE, M. 1996. Planning your next meal: leatherback travel routes and ocean fronts. In: Proceedings of the $15^{\text {th }}$ annual symposium on sea turtle biology and conservation. J. Keinath, D. Barnard, J. A. Musick, B. A. Bell (Eds.):174-178 NOAA Technical Memorandum NMFS-SEFSC-387. Miami.

Lutcavage, M. E., Plotkin, P., Witherington, B., Lutz, P. L. 1997 Human Impacts on Sea Turtle Survival. In: The Biology of Sea Turtles. P. L. Lutz, J. A. Musick (Eds.): 387-409. CRC Press. Florida.

Lutz, P. L., Musick, J. A. 1997. The Biology of Sea Turtles. CRC Press. Florida.

Marine Turtle Specialist Group. 1996. Caretta caretta. In: IUCN 2010. IUCN Red List of Threatened Species. Version 2010.3. $<$ www.iucnredlist.org $>$

MARTIN, C. S. 2003. The Behaviour of Free-living Marine Turtles: Underwater Activities, Migrations \& Seasonal Occurrences. Ph.D. Thesis. University of Wales. Swansea.

Mcmahon, C. R., HaYs, G. C. 2006. Thermal niche, large-scale movements and implications of climate change for a critically endangered marine vertebrate. Glob. Change Biol. 12(7): 1330-1338.

Mrag ltd., Lamans S.A. Management Services, Azti-TeCnalia. 2008 Field study to assess some mitigation measures to reduce bycatch of marine turtles in surface longline fisheries. Final Report to the Directorate-General for Fisheries and Maritime Affairs, FISH/2005/28A

Mrosovsky, N., RyAn, G. D., James, M. C. 2009. Leatherback turtle: The menace of plastic. Mar. Pollut. Bull. 58: 287-289.

Navaz, J. M., Gomez de Llanera, J. 1951. Nota acerca de una tortuga de cuero, "Dermochelys coriácea" (L), capturada en aguas de Guipúzcoa. Publicaciones de la Sociedad de Oceanografía de Guipúzcoa IX: 1-13.

Peckham, S. H., Maldonado Diaz, D., Walli, A., Ruiz, G., Crowder, L. B., Nichols, W. J. 2007. Small-Scale Fisheries Bycatch Jeopardizes Endangered Pacific Loggerhead Turtles. PLOS ONE 2(10): e1041

Penrose, R. S., Gander, L. R. 2010. British Isles \& Republic of Ireland Marine Turtle Strandings \& Sightings. Annual Report 2009. (www.strandings.com).

Pingree, R. D. Griffiths, D. K. 1978. Tidal fronts on the shelf-seas around the British Isles, J. Geophys. Res. 83: 4615-4622.

Pingree, R. D. Le Cann, B. 1992. Three anticyclonic slopewater oceanic eddies (SWODDIES) in the southern Bay of Biscay in 1990. Deep-Sea Research 39(7/8): 1147-1175

Pingree, R. D., Mardell, G. T., Holligan, P. M., Griffiths, D. K SmitheRS, J. 1982. Celtic Sea and Armorican current structure and the vertical distributions of temperature and chlorophyll. Cont. Shelf Res. 1: 99-116.
Pitman, R. L. 1993. Seabird Associations with Marine Turtles in the Eastern Pacific Ocean. Colonial Waterbirds 16(2): 194-201.

Poloczanska, E. S., Limpus, C. J., Hays, G. C. 2009. Vulnerability of Marine Turtles to Climate Change. Adv. Mar. Biol. 56: 151-211.

Polovina, J. J., Uchida, I., Balazs, G., Howell, E. A., PARker, D. DutTon, P. 2006. The Kuroshio extension bifurcation region: a pelagic hotspot for juvenile loggerhead sea turtles. Deep-Sea Research // 53(3-4): 326-339.

Proelss, A., Krivickaite, M., Gilles, A., Herr, H., Siebert, U. 2011. Protection of Cetaceans in European Waters- A Case Study on Bottom-Set Gillnet Fisheries within Marine Protected Areas. Int J. Mar. Coast. Law 26: 5-45

Sarti Martínez, A. L. 2000. Dermochelys coriacea. In: IUCN Red List of Threatened Species. Version 2010.3. <www.iucnredlist.org $>$

Sherrill-Mix, S. A., James, M. C., Myers, R. A. 2007. Migration cues and timing in leatherback sea turtles. Behavioral Ecology 19(2): 231-236.

Shoop, C. R., KenNey, R. D. 1992. Seasonal distribution and abundance of loggerhead and leatherback sea turtles in waters of the northeastern United States. Herpetol. Monogr. 6: 43-67.

Silvani, L., Gazo, M., Aguilar A. 1999. Spanish driftnet fishing and incidental catches in the western Mediterranean. Biol. Conserv 90: 79-85.

Sims, D. W., Witt, M. J., Richardson, A. J., Southall, E., Metcalfe, J. D. 2006. Encounter success of free-ranging marine predator movements across a dynamic prey landscape. Proc. $R$. Soc. Lond. B 273: 1195-1201.

Soykan, C. U, Moore, J. E., Zydelis, R., Crowder, L. B., Safina, C. LEWISON, R. L. 2008. Why study bycatch? An introduction to the Theme Section on fisheries bycatch. Endang. Species Res. 5: 91-102.

Stewart, K., Johnson, C., Godfrey, M. H. 2007. The minimum size of leatherbacks at reproductive maturity, with a review of sizes for nesting females from the Indian, Atlantic and Pacific Ocean basins. Herpetol. J. 17(2): 123-128.

Suarez-Morales, E., Gasca, R., Segura-Puertas, L., Biggs, D. C 2002. Planktonic cnidarians in a cold-core ring in the Gulf of Mexico. Anales del Instituto de Biología, Universidad Nacional Autónoma de México 73(1): 19-36.

Tomás, J., Gozalbes, P., Raga, J. A., Godley, B. 2008. Bycatch of loggerhead sea turtles: insight from 14 years of stranding data. Endang. Species Res. 5: 161-169.

Wallace, B. P., Heppell, S., Lewison, R. L., Kelez, S., Crowder, L. B. 2008. Impacts of fisheries bycatch on loggerhead turtles worldwide inferred from reproductive value analyses. J. Appl. ECOl. 45: 1076-1085

WALLACE, B. P. LEWISON, R. L. MCDONALD, S. L. MCDONALD, R. K. Kot, C. Y., Kelez, S., Buorkland, R. K., Finkbeiner, E. M., HelmBRECHT, S., CROWDER, L. B. 2010. Global patterns of marine turtle bycatch. Conserv. Lett. 3: 131-142.

Witt, M. J., Broderick, A. C., Johns, D. J., Martin, C., Penrose, R., Hoogmoed, M. S., Godley, B. J. 2007a. Prey-landscapes help identify potential foraging habitats for leatherback turtles in the NE Atlantic. Mar. Ecol. Prog. Ser. 337: 231-243.

Witt, M J , PENROSE, R , GODLEy, B J 2007b Spatio-temporal patterns of juvenile marine turtle occurrence in waters of the European continental shelf. Mar. Biol. 151: 873-885.

ZaLduA-MendizABAL, N. 2010. Evaluación de la interacción entre la pesquería de la Comunidad Autónoma Vasca y las tortugas marinas en el golfo de Bizkaia. Proyecto Fin de Máster. Universidad de Valencia. Valencia. 